\title{
Perbedaan Pengaruh Terapi Audio Gelombang Alpha dan Gelombang Theta terhadap Daya Konsentrasi Otak pada Pemuda GMIM Tabita Sarongsong 1 Airmadidi 2
}

\author{
Jooh Kawengian, ${ }^{1}$ Jimmy Rumampuk, ${ }^{2}$ Fransiska Lintong ${ }^{2}$
}

\author{
${ }^{1}$ Program Studi Pendidikan Dokter Fakultas Kedokteran Universitas Sam Ratulangi Manado \\ ${ }^{2}$ Bagian Fisika Fakultas Kedokteran Universitas Sam Ratulangi Manado \\ Email: joohkawengian120111237@gmail.com
}

\begin{abstract}
This study was aimed to determine the differences in the effects of audio alpha and theta waves on brain concentration poweramong youths of GMIM Tabita Sarongsong I Airmadidi II. This was a quantitative study with a cross-sectional design. Samples were 30 youths obtained by using the systematic sampling technique. The brain concentration power was measured by the results of solving modified mathematical problems. Data were analyzed by using descriptive analysis, the normality test of Kolmogrov-Smirnov, the homogeneity Levene test, followed by t-test to obtain the difference in the effects of audio alpha and theta waves on the brain concentration power. The results showed the average test result, as follows: of alpha wave exposure was 8.80 while of theta wave exposure was 8.53 . The t-test analysis showed a p-value of $0.000<0.05$, this meant that there was a significant difference between the effects of audio alpha and theta waves on the brain concentration power. In conclusion, alpha and theta wave therapy could influence the brain concentration power among youths of GMIM Tabita Sarongsong I Airmadidi II, however, theta wave was more effective than alpha wave.
\end{abstract}

Keywords: audio wave therapy, brain concentration power

\begin{abstract}
Abstrak: Penelitian ini bertujuan untuk mengetahui perbedaan pengaruh audio gelombang alpha dan gelombang theta terhadap daya konsentrasi otak pada Pemuda GMIM Tabita Sarongsong I Airmadidi II. Jenis penelitian ialah kuantitatif dengan desain potong lintang. Pengambilan sampel menggunakan teknik sampling sistematis dengan jumlah sampel 30 orang. Daya konsentrasi otak diukur dengan hasil pengerjaan masalah matematika yang dimodifikasi. Analisis data penelitian menggunakan analisis deskriptif, uji normalitas Kolmogrov-Smirnov, uji homogenitas Levene, dilanjutkan uji-t untuk mengetahui perbedaan pengaruh audio gelombang alpha dan gelombang theta. Hasil penelitian menunjukkan bahwa rerata hasil ujian dengan paparan gelombang alpha sebesar 8,80 sedangkan hasil ujian dengan paparan gelombang theta sebesar 8,53. Hasil analisis uji-t menunjukkan nilai $\mathrm{p}=0,000<0,05$. Simpulan penelitian ini ialah terapi audio gelombang alpha dan theta dapat memengaruhi daya konsentrasi otak pada Pemuda GMIM Tabita Sarongsong I Airmadidi II namun gelombang theta lebih berpengaruh daripada gelombang alpha.
\end{abstract}

Kata kunci: terapi audio gelombang, daya konsentrasi otak

\section{PENDAHULUAN}

Saat ini banyak sekali penelitian yang membahas hubungan antara fungsi dan gelombang otak dengan penyakit medis, gangguan psikologis, atau kapasitas manusia terhadap berbagai subjek. Salah satunya ialah dengan pembangkitan potensi-potensi individu menggunakan brainwave, terapi brainwave pada pecandu minuman keras, penanganan anak-anak autis dengan menggunakan stimulasi audio-visual, efektifitas training gelombang alpha pada tentara, 
serta pengobatan penderita penyakit kronis dengan menggunakan stimulasi audiovisual. Berbagai penelitian menunjukkan bahwa kajian tentang otak cukup berkembang. ${ }^{1,2}$ Proses pembelajaran juga dapat dikaitkan dengan terapi brainwave karena gelombang-gelombang ini dapat meningkatkan kinerja otak untuk lebih berkonsentrasi dalam meningkatkan daya memori dan juga kecerdasan, antara lain gelombang alpha dan gelombang theta..$^{2-5}$ Di dalam alam pikiran terdapat dua jenis pikiran yaitu pikiran sadar dan pikiran bawah sadar yang bekerja secara bersamaan dan dalam waktu yang bersamaan tetapi bekerja dengan cara yang berbeda, jadi tidak bekerja secara bergantian. ${ }^{3}$

Electroencephalogram (EEG) adalah alat yang digunakan untuk mengukur dan merekam aktivitas otak manusia. Aktivitas electroencephalogram berkaitan dengan amplitudo dan frekuensi yang terbagi menjadi 4 gelombang yaitu gelombang alpha (8-13 Hz), gelombang beta (13-30 $\mathrm{Hz})$, gelombang theta $(4-7 \mathrm{~Hz})$, dan gelombang delta $(0,5-4 \mathrm{~Hz})$. Masing-masing gelombang memiliki karakteristik yang berbeda-beda serta menandakan kondisi mental seseorang. Gelombang alpha berkaitan dengan keadaan rileks dan tanpa stress. Gelombang alpha sangat kontras dibandingkan dengan kondisi gelombang beta. Kondisi rileks mendorong aliran energi kreativitas dan perasaan segar dan sehat. Kondisi gelombang otak alpha ideal untuk perenungan, memecahkan masalah, dan visualisasi, bertindak sebagai gerbang kreativitas. Keadaan theta adalah keadaan dimana pikiran menjadi kreatif dan inspiratif, serta berhubungan dengan relaksasi mendalam, meditasi, serta peningkatan memori. Kondisi gelombang otak theta muncul saat bermimpi pada tidur ringan, sering dinamakan sebagai mimpi secara sadar. Frekuensi theta ini dihubungkan dengan pelepasan stres dan pengingatan kembali memori yang telah lama. Kondisi "senjakala" (twilight) dapat digunakan untuk menuju meditasi yang lebih dalam, menghasilkan peningkatan kesehatan secara keseluruhan, kebutuhan kurang tidur, meningkatkan kreativitas dan pembelajaran. ${ }^{6}$

Dengung, frekuensi, suara, vibrasi dapat menjadi media terhadap gelombang-gelombang otak sesuai dengan frekuensinya. Pada proses peningkatan kinerja otak dengan meningkatkan kemampuan pikiran bawah sadar dalam hal berkonsentrasi dan lebih membuka cara berpikir, dapat digunakan gelombang alpha dan theta yang diperoleh dari suara, bisa melalui audio yang didengarkan dikehidupan sehari-hari misalnya musik. $^{4}$

\section{METODE PENELITIAN}

Penelitian ini dilaksanakan di gedung gereja GMIM Tabita. Subyek penelitian sebanyak 30 orang pemuda GMIM Tabita Sarongsong 1 Airmadidi 2. Jenis penelitian ini ialah kuantitatif dengan desain potong lintang.

Perlakuan yang diberikan dalam penelitian ini ialah sebagai berikut: Sebelum paparan gelombang alpha dan tetha, subyek diberikan 10 soal matematika, kemudian dilakukan paparan gelombang alpha selama 5 menit dan diberikan lagi 10 soal matematika yang berbeda dengan derajat kesulitan yang sama, dilanjutkan dengan pemberian paparan gelombang theta selama 5 menit dan diberikan lagi soal metamatika dengan derajat kesulitan yang sama. Analisis data menggunakan uji normalitas Kolmogrov-Smirnov, uji homogenitas Levene, dan dilanjutkan dengan uji-t untuk mengetahui perbedaan pengaruh audio gelombang alpha dan gelombang theta.

\section{HASIL PENELITIAN}

Tabel 1 memperlihatkan bahwa sebelum paparan gelombang alpha, subyek yang terbanyak berada pada kategori baik berjumlah 10 orang $(33,3 \%$, disusul oleh kategori sangat baik berjumlah 7 orang $(23,3 \%)$.

Tabel 2 memperlihatkan bahwa sesudah paparan gelombang alpha didapatkan subyek terbanyak berada pada kategori lebih dari baik berjumlah 12 orang $(40,0 \%)$, disusul kategori baik berjumlah 9 orang $(30,0 \%)$. 
Tabel 3 memperlihatkan bahwa sesudah paparan gelombang theta didapatkan subyek yang terbanyak berada pada kategori baik berjumlah 12 orang $(40,0 \%)$, disusul oleh kategori sangat baik berjmlah 8 orang $(26,7 \%)$.

Tabel 4 memperlihatkan perbandingan hasil tes sebelum dan sesudah paparan gelombang alpha pada pemuda GMIM Tabita. Sebelum paparan dengan gelombang alpha masih ada subyek yang mendapatkan hasil 6 yaitu 2 orang $(6,7 \%)$ sedangkan sesudah paparan gelombang alpha tidak ada lagi subyek yang mendapatkan nilai 6. Sebelum paparan gelombang alpha terdapat 6 subyek yang mendapatkan nilai $7(20,0 \%)$ sedangkan sesudah paparan gelombang alpha hanya 2 subyek $(6,7 \%)$ yang mendapatkan nilai 7 . Nilai 8 terdapat pada 10 subyek $(33,3 \%)$ sebelum paparan gelombang alpha dan 9 subyek $(30,0 \%)$ sesudah paparan gelombang alpha. Sebelum paparan gelombang alpha terdapat 5 subyek $(16,7 \%)$ yang mendapatkan nilai 9 sedangkan sesudah paparan gelombang alpha meningkat menjadi 12 subyek $(40,0 \%)$. Nilai 10 didapatkan pada 7 subyek $(23,3 \%)$ baik sebelum dan sesudah paparan gelombang alpha.

Tabel 5 memperlihatkan bahwa sesudah paparan gelombang theta terdapat perubahan pada hasil tes yaitu sebelum paparan gelombang terdapat 2 subyek $(6,7 \%)$ mendapatkan nilai 6 sedangkan sesudah paparan tidak ada lagi yang mendapat nilai 6 .

Tabel 1. Distribusi frekuensi dan persentase hasil tes sebelum paparan gelombang alpha dan gelombang theta

\begin{tabular}{cccc}
\hline Nilai ujian & $\begin{array}{c}\text { Frekuensi } \\
(\mathbf{N})\end{array}$ & $\begin{array}{c}\text { Persentase } \\
(\boldsymbol{\%})\end{array}$ & Kategori \\
\hline 6 & 2 & 6,7 & Cukup \\
7 & 6 & 20,0 & Lebih dari cukup \\
8 & 10 & 33,3 & Baik \\
9 & 5 & 16,7 & Lebih dari baik \\
10 & 7 & 23,3 & Sangat baik \\
Jumlah & 30 & 100 & \\
\hline
\end{tabular}

Tabel 2. Distribusi frekuensi dan persentase hasil tes sesudah paparan gelombang alpha

\begin{tabular}{cccc}
\hline Nilai ujian & $\begin{array}{c}\text { Frekuensi } \\
(\mathbf{N})\end{array}$ & $\begin{array}{c}\text { Persentase } \\
(\boldsymbol{\%})\end{array}$ & Kategori \\
\hline 7 & 2 & 6,7 & Lebih dari cukup \\
8 & 9 & 30,0 & Baik \\
9 & 12 & 40,0 & Lebih dari baik \\
10 & 7 & 23,3 & Sangat baik \\
Jumlah & 30 & 100 & \\
\hline
\end{tabular}

Tabel 3. Distribusi frekuensi dan persentase hasil tes sesudah paparan gelombang theta

\begin{tabular}{cccc}
\hline Nilai ujian & $\begin{array}{c}\text { Frekuensi } \\
(\mathbf{N})\end{array}$ & $\begin{array}{c}\text { Persentase } \\
(\boldsymbol{\%})\end{array}$ & Kategori \\
\hline 7 & 5 & 16,7 & Lebih dari cukup \\
8 & 12 & 40,0 & Baik \\
9 & 5 & 16,7 & Lebih dari baik \\
10 & 8 & 26,7 & Sangat baik \\
Jumlah & 30 & 100 & \\
\hline
\end{tabular}


Pada nilai 7 terdapat 6 subyek 20,0\%) sebelum paparan dan 5 subyek $(16,7 \%)$ sesudah paparan gelombang theta. Sebelum paparan gelombang theta terdapat 10 subyek dengan nilai $8(33,3 \%)$ sedangkan sesudah paparan meningkat menjadi 12 subyek (40,0\%). Pada nilai 9, sebelum dan sesudah paparan gelombang theta berjumlah sama yaitu 5 subyek $(16,7 \%)$. Yang terakhir ialah terdapat 7 orang $(23,3 \%)$ dengan hasil tes 10 sebelum paparan, sedangkan sesudah paparan gelombang theta meningkat menjadi 8 subyek $(26,7 \%)$.

Tabel 6 memperlihatkan terdapat per- bedaan frekuensi di setiap nilai ujian sesudah paparan gelombang alpha dan gelombang theta. Pada hasil ujian dengan nilai 7 , gelombang alpha sebanyak 2 subyek sedangkan gelombang theta 5 subyek, pada nilai 8 terdapat 9 subyek setelah paparan gelombang alpha dan 12 subyek setelah paparan gelombang theta, pada hasil nilai ujian 9 setelah paparan gelombang alpha ialah 12 subyek sedangkan gelombang theta sebanyak 5 subyek dan pada nilai 10 setelah paparan gelombang theta sebanyak 7 subyek dan gelombang theta sebanyak 8 subyek.

Tabel 4. Distribusi frekuensi dan persentase hasil tes sebelum dan sesudah paparan gelombang alpha

\begin{tabular}{ccccc}
\hline Nilai Ujian & \multicolumn{2}{c}{ Frekuensi } & \multicolumn{2}{c}{ Persentase (\%) } \\
& Sebelum & Sesudah & Sebelum & Sesudah \\
\hline 6 & 2 & 0 & 6,7 & 0 \\
7 & 6 & 2 & 20,0 & 6,7 \\
8 & 10 & 9 & 33,3 & 30,0 \\
9 & 5 & 12 & 16,7 & 40,0 \\
10 & 7 & 7 & 23,3 & 23,3 \\
Jumlah & & 30 & & \multicolumn{2}{c}{100} \\
\hline
\end{tabular}

Tabel 5. Distribusi frekuensi dan persentase hasil tes sebelum dan sesudah paparan gelombang theta

\begin{tabular}{|c|c|c|c|c|}
\hline \multirow[t]{2}{*}{ Nilai Ujian } & \multicolumn{2}{|c|}{ Frekuensi } & \multicolumn{2}{|c|}{ Persentase (\%) } \\
\hline & Sebelum & Sesudah & Sebelum & Sesudah \\
\hline 6 & 2 & - & 6,7 & - \\
\hline 7 & 6 & 5 & 20,0 & 16,7 \\
\hline 8 & 10 & 12 & 33,3 & 40,0 \\
\hline 9 & 5 & 5 & 16,7 & 16,7 \\
\hline 10 & 7 & 8 & 23,3 & 26,7 \\
\hline Jumlah & \multicolumn{2}{|c|}{30} & \multicolumn{2}{|c|}{100} \\
\hline
\end{tabular}

Tabel 6. Distribusi frekuensi dan persentase hasil tes sesudah paparan gelombang alpha dan gelombang theta

\begin{tabular}{ccccc}
\hline Nilai ujian & \multicolumn{2}{c}{ Frekuensi } & \multicolumn{2}{c}{ Persentase (\%) } \\
& Alpha & Theta & Alpha & Theta \\
\hline 7 & 2 & 5 & 6,7 & 16,7 \\
8 & 9 & 12 & 30,0 & 40,0 \\
9 & 12 & 5 & 40,0 & 16,7 \\
10 & 7 & 8 & 23,3 & 26,7 \\
Jumlah & \multicolumn{2}{c}{30} & \multicolumn{2}{c}{100} \\
\hline
\end{tabular}




\section{BAHASAN}

Pada penelitian ini diberikan terapi brainwave entrainment dengan jenis gelombang alpha dan gelombang theta terhadap pemuda GMIM Tabita sebagai subyek. Pretest terdiri dari hasil tes soal matematika sebelum brainwave entrainment dan posttest ialah hasil tes soal matematika sesudah brainwave entrainment pada subyek. Brainwave entrainment yang diberikan ialah terapi gelombang otak dengan menggunakan gelombang alpha dan gelombang theta. Bentuk tes berupa soal matematika sebanyak 10 nomor. Tes dilakukan 3 kali yaitu tes pertama sebelum diberikan paparan gelombang alpha dan theta, kemudian tes kedua diberikan paparan gelombang alpha dan ketiga ialah tes setelah paparan gelombang theta.

Berdasarkan hasil tes sebelum paparan gelombang alpha dan theta didapatkan nilai rerata 8,30 ( $\mathrm{SD} \pm 1,236)$; hasil tes dengan paparan gelombang theta didapatkan nilai rerata8,80 $(\mathrm{SD} \pm 0,887)$; sedangkan hasil tes setelah paparan gelombang theta didapatkan nilai rerata 8,53 (SD $\pm 1,074)$. Setelah dilakukan uji independent sampel t-test menggunakan SPSS versi 25 didapatkan bahwa hasil tes dengan paparan gelombang alpha tidak bermakna karena nilai sig (2tailed) 0,893 yang lebih besar 0,05. Oleh karena perubahan hasil tes sebelum dan sesudah paparan gelombang alpha tidak mengalami perbedaan bermakna maka dapat disimpulkan bahwa daya konsentrasi otak sebelum dan sesudah paparan gelombang alpha pada subyek relatif sama. Setelah paparan dengan gelombang theta didapatkan nilai sig (2-tailed) 0,00 lebih kecil dari 0,05. Oleh karena perubahan hasil tes sebelum dan sesudah paparan gelombang theta mengalami perbedaan bermakna maka dapat disimpulkan bahwa daya konsentrasi otak sebelum dan sesudah paparan gelombang theta pada subyek berbeda bermakna. Dengan demikian gelombang theta lebih memengaruhi daya konsentrasi otak daripada gelombang alpha. Berdasarkan hasil penelitian, bila digabungkan, kedua gelombang ini dapat meningkatkan daya konsentrasi otak karena hasil tes sebelum dan sesudah paparan gelombang alpha dan theta mengalami perubahan.

Hasil penelitian ini telah membuktikan bahwa terapi brainwave entrainment dengan gelombang alpha dan theta dapat meningkatkan hasil tes matematika pada subyek yaitu pemuda GMIM Tabita. Sebagaimana penelitian pendidikan lainnya, meningkatnya hasil belajar juga dapat dipengaruhi oleh variabel lain yang tidak dapat dikontrol. Demikian pula pada penelitian ini. Subyek yang diberikan terapi gelombang otak menggunakan gelombang audio juga dipengaruhi oleh variabel lain yang tidak dapat dikontrol, misalnya banyaknya suara mobil yang berlalulalang di jalan depan gereja cukup menambah kebisingan ketika peneliti sedang memberi terapi gelombang otak melalui gelombang audio yang dihasilkan oleh headset. Untuk mendapatkan hasil yang maksimal dalam melakukan terapigelombang otak (brainwave entrainment) dengan menggunakan gelombang audio, maka tempat terapi sebaiknya dilakukan di ruangan yang memiliki sistem kedap suara.

\section{SIMPULAN}

Terapi gelombang otak berpengaruh terhadap daya konsentrasi otak pada manusia. Terdapat perbedaan pengaruh antara paparan gelombang alpha dan gelombang theta, yaitu gelombang theta lebih berpengaruh terhadap daya konsentrasi otak daripada gelombang alpha.

\section{Konflik Kepentingan}

Penulis menyatakan tidak terdapat konflik kepentingan dalam studi ini.

\section{DAFTAR PUSTAKA}

1. Brainwave Entrainment. [cited 2019 Oct 9]. Available from: http://brainwave.co.id.

2. Mustajib A. Rahasia Dahsyat Terapi Otak Audio MP3 (Cetakan I). Jakarta: Wahyu Media, 2010.

3. Rakhmat J. Belajar Cerdas Belajar Berbasiskan Otak.Bandung: MLC, 2005.

4. Gelombang otak manusia. [cited 2019 Oct 9]. Available from: http://www.gelombang 
76 Medical Scope Journal (MSJ), Volume 1, Nomor 2, Januari-Juni 2020, hlm.71-76

otak.com/teknologi-gelombang-otak.

htm

5. Gunawan D. Kedahsyatan dan Kekuatan Gelombang Otak (Cetakan I). Jakarta: PT Elex Media Komputindo, 2011.
6. Schromer DL, da Silva FHL. Niedermeyer's Electroencephalography: Basic Principles, Clinical Application, and Related Fields. Philadelphia: Two Commerce Square, 2001. 